\title{
Bioprospecting rhizobacteria associated to cacti to water stress resistance and biofilm formation
}

\section{Clayton dos Santos Silva ${ }^{1}$, João Manoel da Silva ${ }^{2}$, José Ubaldo Lima de Oliveira ${ }^{3}$, Romário Guimarães Verçosa de Araújo $^{3}$, Jessé Rafael Bento de Lima ${ }^{1}$, Erica Livea Ferreira Guedes ${ }^{1}$, Micheline Thais dos Santos ${ }^{4}$, Yamina Coentro Montaldo $^{3}$ and Tania Marta Carvalho dos Santos ${ }^{3}$}

\begin{abstract}
${ }^{1}$ Programa de Pós-Graduação em Desenvolvimento e Meio Ambiente. Universidade Federal de Pernambuco. Av. Prof. Moraes Rego, 1235. Cidade Universitária. Recife-PE (CEP 50670-901).

${ }^{2}$ Rede Nordeste de Biotecnologia. Instituto de Química e Biotecnologia. Universidade Federal de Alagoas. Av. Lourival Melo Mota, S/№. Tabuleiro do Martins. Maceió-AL, Brasil (CEP 57072-900). Email: joao.manoel@iqb.ufal.br.

${ }^{3}$ Centro de Ciências Agrárias. Universidade Federal de Alagoas. Rodovia BR-104, S/№. Rio Largo -AL, Brasil (CEP 57100-000).

${ }^{4}$ Programa de Pós-Graduação em Biociência Animal. Universidade Federal Rural de Pernambuco. Rua Dom Manoel de Medeiros, S/№. Dois Irmãos. Recife-PE (CEP 52171-900).
\end{abstract}

\begin{abstract}
The aim of this study was to isolate and select bacteria from the cacti rhizosphere naturally occurring in an adverse environment in culture medium under water stress. Samples of rhizospheric cacti soil were collected in two distinct locations with natural occurrence of the Caatinga vegetation of the Alagoas State, Northeast Brazil. With the use of culture-dependent methodologies, the isolation and purification of the bacteria was performed for exopolysaccharide production analyzes by quantification of halos and biofilm formation in a spectrophotometer under optical density (OD) of $560 \mathrm{~nm}$. In total, 42 strains were isolated, with the isolates BCM02, BCM06, BCM10 and BCM13 being the major producers of EPS, followed by bacteria $\mathrm{BCM} 01, \mathrm{BCM} 05, \mathrm{BCM} 28$ and $\mathrm{BCM} 35$ with medium production, and bacteria BCM22 and BCM33 with low production. On the other hand, for the biofilm formation, all the isolates were efficient in the synthesis of the same, being $38 \%$ of the bacteria with high formation performance. Thus, strains BCM02 and BCM28 presented the best results in evaluations of water stress tolerance mechanisms, and could later be used for future tests to promote plant growth.
\end{abstract}

Keywords: Growth promotion bacteria; Exopolyssacharides; Tolerant bacteria.
Received

October 03, 2019

Accepted

December 24, 2019

Released

December 31, 2019

Acesso aberto

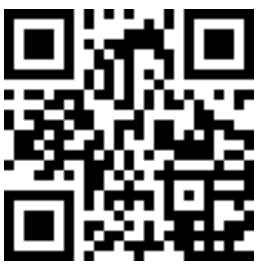

0000-0003-3924-5526

Clayton dos Santos Silva 
Resumo. Bioprospecção de rizobactérias associadas a cactos para resistência ao estresse hídrico e formação de biofilme. 0 objetivo deste estudo foi isolar e selecionar bactérias da rizosfera de cactos que ocorrem naturalmente em um ambiente adverso em meio de cultura sob estresse hídrico. Amostras de solo rizosférico de cactáceas foram coletadas em dois locais distintos, com ocorrência natural da vegetação da Caatinga no Estado de Alagoas, Nordeste do Brasil. Com o uso de metodologias dependentes da cultura, o isolamento e a purificação das bactérias foram realizados para análises de produção de exopolissacarídeos por quantificação de halos e formação de biofilme em um espectrofotômetro sob densidade óptica de 560 $\mathrm{nm}$. No total, foram isoladas 42 linhagens, sendo os isolados BCM02, BCM06, BCM10 e BCM13 os maiores produtores de EPS, seguidos pelas bactérias BCM01, BCM05, BCM28 e BCM35 com produção média e bactérias BCM22 e BCM33 com baixa produção. Por outro lado, para a formação de biofilme, todos os isolados foram eficientes na síntese dos mesmos, sendo 38\% das bactérias com alto desempenho de formação. Assim, as linhagens BCM02 e BCM28 apresentaram os melhores resultados nas avaliações dos mecanismos de tolerância ao estresse hídrico, podendo posteriormente ser utilizadas em testes futuros para promover o crescimento das plantas.

Palavra-chave: Bactéria promotora de crescimento; Exopolissacarídeos; Bactéria tolerante.

\section{Introduction}

Water is essential for the maintenance of life and essential for the production of food (Pimentel et al., 2004). However, due to the constant climatic adversities and the misuse of this resource, the Brazilian agricultural sector has suffered serious consequences, limiting the activity in the country.

The United Nations Food and Agriculture Organization (FAO, 2011) estimates that $70 \%$ of the world's freshwater (potable water) is used exclusively for agriculture (irrigation), $20 \%$ for industrial use and $10 \%$ for domestic purposes. In the production of about $1 \mathrm{~kg}$ of irrigated rice (Oryza sativa), 2,300 L of water are spent; for cereals in general, the average is around 1,500 L.kg-1, for citrus fruits, 1,000 L.kg-1 and for the production of maize (Zea mays), are spent about 900 L.kg-1.

\author{
D $0000-0002-7654-5475$ \\ João Manoel da Silva \\ D 0000-0002-4074-8393 \\ José Ubaldo Lima de \\ Oliveira \\ D 0000-0001-6150-9829 \\ Romário Guimarães \\ Verçosa de Araújo \\ (1) 0000-0003-3439-8697 \\ Jessé Rafael Bento de \\ Lima \\ (D) $0000-0003-2157-0750$ \\ Erica Livea Ferreira \\ Guedes \\ D) 0000-0002-7675-2554 \\ Micheline Thais dos \\ Santos \\ D) $0000-0003-1444-8642$ \\ Yamina Coentro \\ Montaldo \\ (ㄱ) $0000-0002-1816-7840$ \\ Tania Marta Carvalho \\ dos Santos
}

In view of the described situation, the concern for alternatives to reduce water consumption by crops, to promote the growth of plants in soils with low water precipitation, as observed in some regions of the Northeast and to recover areas in the process of desertification. Therefore, the use of drought tolerant microorganisms capable of protecting plants and promoting their growth under water stress is an alternative to this problem (Kavamura et al., 2013).

The cacti are plants of the Cactaceae Family, which have around 176 genera and about 2,200 species, which have adapted and developed mechanisms over time that have allowed them to live in dry and warm environments. They are mainly distributed in the Americas and are characterized by a juicy stem filled with spines (Arruda et al., 2005).

However, as these plants adapted to their habitat and evolved to their 
survival, the microorganisms associated with these plants also underwent adaptations that gave them tolerance to environments with low water availability, and, on top of that, plant protection against certain environmental adversities (Kavamura et al., 2013).

In addition to cellular protection, it is believed that microorganisms can also offer vegetal protection against desiccation, by maintaining a humid environment conducive to root development, nutrient supply, and hormones, also acting as growth promoters. In addition, the microorganisms can be obtained by means of various mechanisms such as the production of exopolysaccharides (EPS) (Nocker et al., 2012; Montaldo, 2016; Silva et al., 2018) and biofilm formation (Chang et al., 2007; Montaldo, 2016).

Exopolysaccharides are defined as extracellular polysaccharides where innumerable microorganisms have the ability to produce them, bound to the surface of cells or excreted into the medium. This mechanism of tolerance allows adaptation to several types of environmental stresses such as water, saline and temperature variations (Schiavão-Souza et al., 2007) and allows free life to the bacteria, allowing adhesion and colonization on solid surfaces , the involvement of cell membranes against desiccation, and the fixation of nutrients close to the bacteria (Barreto et al., 2011).

Exopolysaccharides also help microorganisms to colonize the roots due to the involvement of biofilms that permanently connect to the root surface. Biofilm, another mechanism of tolerance to water stress, consists of bacterial communities surrounded by substances exuded by the bacteria themselves, being free when released from the community, having the advantage of protecting against several external aggressions, such as lack of nutrients and protection against the loss of water (Boari et al., 2009).
The mechanisms described help the colonization of the root system by microorganisms, giving protection to environmental stresses, thus promoting resistance to plants and providing their growth and productivity in environments with low water availability. In view of the above, the objective was to prospect, isolate and select rhizospheric soil bacteria from Caatinga cacti, with ability to grow in medium with reduced water activity.

\section{Material and methods}

\section{Study area and soil sampling}

A collect of rhizospheric soil (10 cm of surface depth) were carried out on Piranhas and Olho d'Água do Casado, both located in the backlands of the State of Alagoas, Brazil. Two random points were selected in each municipality, and three cacti were selected for collection. From each plant was collected soil samples, with the subsequent mixing of the same, forming a composed sample of soil per plant. After collection, the samples were stored in appropriate paper bags, for the best preservation of the material.

\section{selection \\ Bacterial isolation and}

For the isolation of the rhizospheric soil bacteria, $1 \mathrm{~g}$ of soil was transferred to erlenmeyers containing 10 $\mathrm{mL}$ of buffer (Araújo et al., 2002). The solution was shaked for 1 hour in a mechanical orbital shaker. After shaking, serial dilutions were made up to $10^{-5}$, followed by transfer of $100 \mu \mathrm{L}$ of appropriate dilutions, later seeded in Petri dishes containing Tryptone Soy Agar (TSA) culture medium (10\%), the number of colony forming units (CFU) being estimated.

For the selection of resistant rhizobacteria, the TSA isolates $(10 \%)$ were seeded in medium with three different concentrations of mannitol (285 g/L, $520 \mathrm{~g} / \mathrm{L}$ and $780 \mathrm{~g} / \mathrm{L})$, yielding Water activity (Aw) corresponding to 
0.957, 0.897 and 0.807, respectively, and incubated at $40{ }^{\circ} \mathrm{C}$. Bacterial isolates were purified by the composite streak technique, stored in TSA culture medium $(10 \%)$ in a sloped test tube and then stored in $2 \mathrm{~mL}$ cryogenic tubes containing $50 \%$ glycerol at $18{ }^{\circ} \mathrm{C}$.

\section{Exopolyssacharides production assay}

Was incubated $5 \mu \mathrm{L}$ of the bacterial isolates grown on TSB culture medium $(10 \%)$ were inoculated into 5 $\mathrm{mm}$ sterile filter paper disks in modified culture medium from Guimarães et al. (1999), added with $10 \%$ sucrose, in a factorial design with 3 replicates.

The production of EPS was characterized visually by measuring the halo produced with the aid of an electronic caliper, being + (low yield EPS halo $\leq 10 \mathrm{~mm} \emptyset$ ), ++ (middle yield EPS halo of 10-14 $\mathrm{mm} \emptyset$ ) and +++ (optimum yield - EPS halo $\geq 14 \mathrm{~mm} \emptyset$ )). The confirmation of the production was performed by the chemical method, mixing the platinum handle impregnated with the colony in $2 \mathrm{~mL}$ of ethyl alcohol (Paulo, 2010).

Subsequently, $100 \mu \mathrm{L}$ of the bacterial isolates grown in TSB culture medium were inoculated into polypropylene tubes with $900 \mu \mathrm{L}$ of TSB $(10 \%)$ added to five different concentrations of sorbitol $(0.03 \mathrm{M}, 0.06$ $\mathrm{M}, 0.30 \mathrm{M}, 0.60 \mathrm{M}$ and without sorbitol, corresponding to the control). After incubation at $40{ }^{\circ} \mathrm{C}$ for $96 \mathrm{~h}$, the contents of each tube were homogenized and the absorbance in a spectrophotometer at $600 \mathrm{~nm}$ was checked for bacterial growth.

The cells were removed and each tube was washed three times with distilled water, followed by addition of $1000 \mu \mathrm{L}$ of violet crystal solution in each tube. After 15 min of incubation at room temperature the tubes were washed agaim three times with distilled water (Montaldo, 2016).

\section{Biofilm formation}

The biofilm formation was quantified by the addition of $1000 \mu \mathrm{L}$ of ethyl alcohol (95\%) in each tube to solubilize the violet crystal incorporated into the cell wall. The optical density of the solubilized dye was determined in a spectrophotometer at $560 \mathrm{~nm}$ (O'Toole and Kolter, 1998).

\section{Results}

The bacterial strains obtained were stored in a freezer, totalizing 42 bacterial strains. In relation to the growth in culture medium, the highest amount of isolates in the medium with mannitol concentration of $285 \mathrm{~g} / \mathrm{L}$ (Aw $=0.957$ ) was obtained, which is the one with the highest water activity, of the three concentrations analyzed. The higher the water activity, the faster the microorganisms will be able to grow.

After the incubation period, the halos formed around the paper discs were measured with the aid of a digital pachymeter, where the mean production of each strain was verified and divided into three groups: low, middle and high production of EPS, where + (low production - EPS halo $\leq 10 \mathrm{~mm} \emptyset$ ), ++ (middle production - EPS halo of 10-14 $\mathrm{mm} \varnothing$ ) and +++ (optimal production EPS halo $\geq 14 \mathrm{~mm} \emptyset$ ). Figure 1 illustrates the reading of the qualitative tests for the production of EPS by means of the disc method, and it is possible to visualize the EPS production by the lineages, through the formation of a mucoid substance around the disc, where the absence of this substance caracterizes nonproducing strains. 


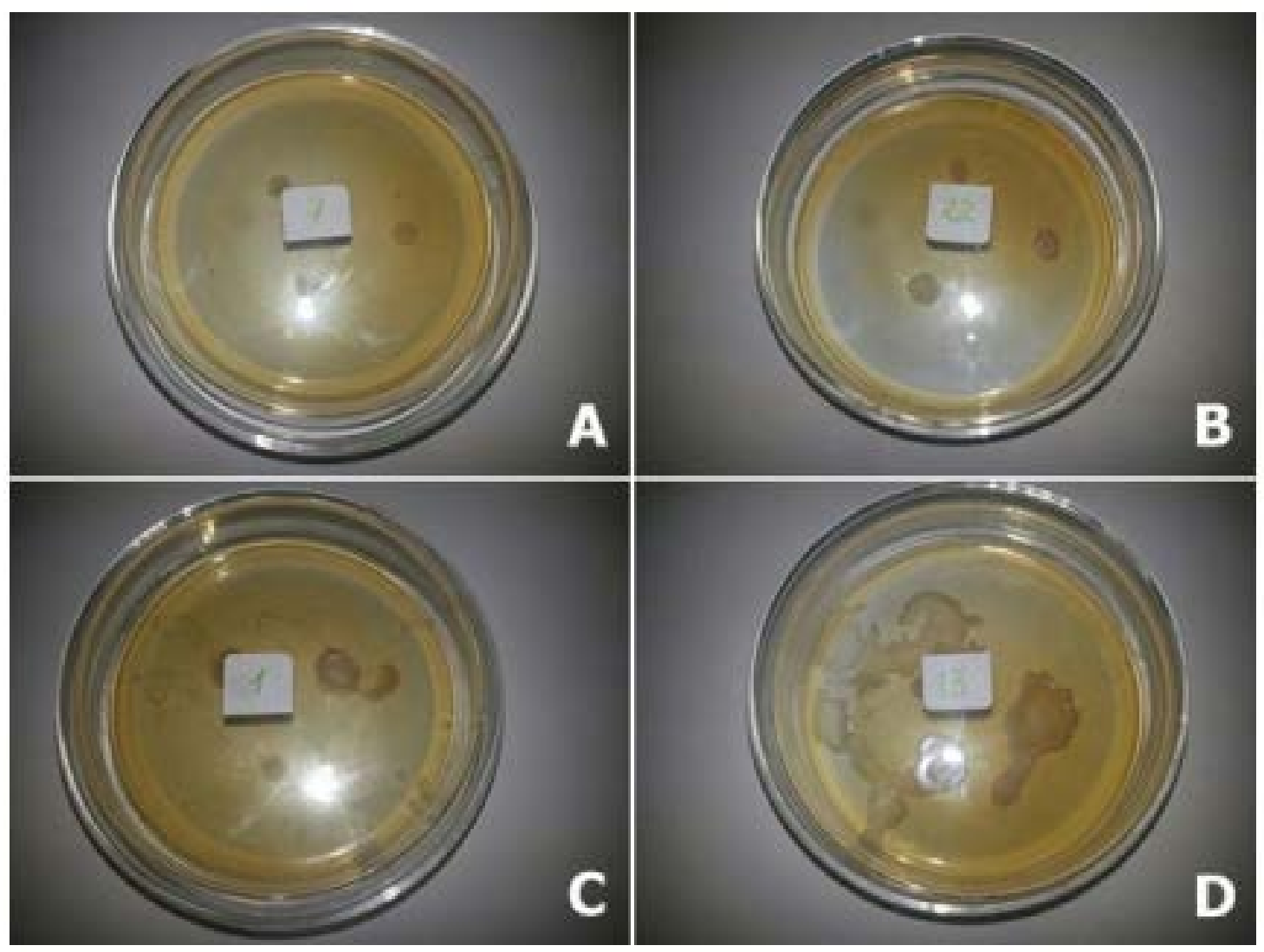

Figure 1. EPS production by rhizobacteria isolated from cacti.

Confirmation of the EPS production was performed by the chemical method. It was observed that of the 11 halo-producing isolates, strain 4 was not characterized as a producer of exopolysaccharides, since even if the isolates produce a halo, the non-EPS producing strains when mixed in ethyl alcohol are suspended, leaving the medium what happened to the bacteria in question. The exopolysaccharides produced by the strains, when mixed in ethyl alcohol, are precipitated, since EPS is insoluble in alcohol.

From the totality of bacterial strains extracted from plant materials collected in Alagoan Caatinga, 23.80\% synthesized EPS in medium with restricted water activity (Table 1 ).
Table 1. Production of exopolysaccharides (EPS) by bacterial strains isolated from rhizospheric cactaceous soil from the Alagoan sertão.

\begin{tabular}{ll}
\hline Isolate & EPS production* \\
\hline BCM01 & ++ \\
BCM02 & +++ \\
BCM05 & ++ \\
BCM06 & +++ \\
BCM10 & +++ \\
BCM13 & +++ \\
BCM22 & + \\
BCM28 & ++ \\
BCM23 & + \\
BCM35 & ++ \\
\hline
\end{tabular}

$*(+)$ low production; $(++)$ miccle production; $(+++)$ high production. 
For the biofilm production tests, only 36 isolates were evaluated in order to determine the best parameters for the measurements. The presence of biofilm on the abiotic surface was evidenced by the formation of a violet coloration.

The biofilm formation was performed in four concentrations of sorbitol $(0.03 \mathrm{M}, 0.06 \mathrm{M}, 0.30 \mathrm{M}, 0.60 \mathrm{M})$ and without sorbitol, simulating different levels of water stress, however the formation of the same did not differ statistically between the different concentrations, and the isolates were compared for the capacity of formation in medium with reduced water activity. The results are shown in Table 2, where all the isolates were efficient in biofilm formation.

Table 2. Formation of biofilm on abiotic surface by bacterial isolates in TSB medium supplemented with $10 \%$ sucrose based on absorbance values obtained OD $560 \mu \mathrm{m}$, according to Scott-Knott's test.

\begin{tabular}{lclc}
\hline Isolate & Biofilm production* & Isolate & Biofilm production* \\
\hline BMC01 & $0.93195 \mathrm{~b}$ & BMC22 & $0.80874 \mathrm{~b}$ \\
BMC02 & $1.54237 \mathrm{a}$ & BMC24 & $1.94397 \mathrm{a}$ \\
BMC03 & $1.76733 \mathrm{a}$ & BMC25 & $0.37360 \mathrm{~b}$ \\
BMC04 & $0.91772 \mathrm{~b}$ & BMC26 & $1.97850 \mathrm{a}$ \\
BMC05 & $0.66498 \mathrm{~b}$ & BMC28 & $1.86382 \mathrm{a}$ \\
BMC06 & $1.23846 \mathrm{~b}$ & BMC29 & $2.47920 \mathrm{a}$ \\
BMC07 & $0.45400 \mathrm{~b}$ & BMC30 & $0.58641 \mathrm{~b}$ \\
BMC08 & $0.77147 \mathrm{~b}$ & BMC31 & $0.92327 \mathrm{~b}$ \\
BMC09 & $0.44752 \mathrm{~b}$ & BMC33 & $1.16353 \mathrm{~b}$ \\
BMC10 & $0.83642 \mathrm{~b}$ & BMC34 & $0.76059 \mathrm{~b}$ \\
BMC11 & $1.36859 \mathrm{a}$ & BMC35 & $1.18309 \mathrm{~b}$ \\
BMC12 & $0.47149 \mathrm{~b}$ & BMC36 & $0.84238 \mathrm{~b}$ \\
BMC13 & $0.88171 \mathrm{~b}$ & BMC37 & $0.56398 \mathrm{~b}$ \\
BMC14 & $0.64888 \mathrm{~b}$ & BMC38 & $0.37188 \mathrm{~b}$ \\
BMC15 & $0.32421 \mathrm{~b}$ & BMC39 & $2.23971 \mathrm{a}$ \\
BMC16 & $1.04795 \mathrm{~b}$ & BMC40 & $1.77706 \mathrm{a}$ \\
BMC17 & $0.87133 \mathrm{~b}$ & BMC41 & $1.76699 \mathrm{a}$ \\
BMC18 & $1.08905 \mathrm{~b}$ & BMC42 & $2.49460 \mathrm{a}$ \\
\hline
\end{tabular}

*Means followed by the same letter do not differ statistically from one another by the Skott-Knott test $(\mathrm{p} \leq 0.05)$.

\section{Discussion}

The results differ from those found by Montaldo (2016) in bacteria associated with sugarcane (Saccharum officinarum), whose majority of the isolates obtained had low production of exopolysaccharides (54\%), followed by medium production strains (42\%) and high production (4\%), which presupposes that the amount produced of this substance differs according to the associated plant. As sugarcane is a very widespread agricultural crop, with great expressiveness in Brazil, it receives all the necessary conditions for its normal development, such as fertilization, pest and disease control and irrigation, and as generally the supply of water in the fields of production is constant, it does not require strategies and physiological changes to resist water scarcity, therefore, the bacteria associated with sugarcane studied by Montaldo (2016), had in their great majority, low production, because the own environment where these microorganisms are inserted has normal water 
availability, and does not need to synthesize defense mechanisms to environmental stresses, unlike cacti, whose scarce environment promotes the adaptation of all living organisms.

Ashraf et al. (2005) evaluating exopolysaccharide-producing bacteria, observed that they promoted mechanisms of tolerance to saline stress in inoculated wheat plants, improving the physical-chemical characteristics of the soil. Therefore, the synthesis of exopolysaccharides can be an efficient tool to combat this stress, since according to FAO (2000), salinity affects around 397 million hectares worldwide, out of a total of 230 million irrigated hectares, 45 million are salinized, limiting agricultural activity and drastically increasing desertified or in process areas.

Therefore, the halotolerant bacteria associated to xerophytes are capable of producing EPS, directly helping to protect the plant against several types of stresses, besides favoring root development and improving soil quality (Silva et al., 2016).

From the total number of strains evaluated, 11 obtained high biofilm formation, which presupposes the high efficiency with respect to the synthesis of the mechanism and the tolerance of the bacteria, which will aid in promoting the growth of the colonized plants, since the biofilm formation appears to be a widely disseminated feature among bacteria, given the positive formation among the isolates evaluated. The formation of biofilms can be an intimate relation between plant and microorganism, and that it product not only of bacterial exopolysaccharides but also of compounds that are excreted and/or produced by the plant that stimulate the formation of biofilms according to the species, as well as the environment (Silva et al., 2018).

This mechanism, together with exopolysaccharides, assists in root colonization, protecting plant cells from environmental stresses, contributing to the absorption of nutrients present in the soil solution and the synthesis of essential hormones for the growth, development and establishment of vegetables in the environment, ensuring the growth, development and quality of Brazilian agricultural production.

\section{Conclusions}

Of all bacterial isolates evaluated, the strains BCM02 and BCM28 were the ones that obtained the best performance in the assessments of water stress tolerance, since they were efficient in the synthesis of both evaluated mechanisms, and could be used later growth promotion tests in plants, such as the aid in the synthesis of plant hormones such as indole-acetic acid (AIA), the solubilization of inorganic phosphates, nitrogen fixation in a nitrogen-free environment, among others.

\section{Acknowledgment}

$\mathrm{CNPq}$ and Universidade Federal de Alagoas for financial and institutional support.

\section{Conflict of interests}

Authors declare that they have no conflict of interests.

\section{References}

Araújo, W. L.; Lima A. O. S.; Azevedo, J. L.; Marcon, J. Manual de isolamento de microrganismos endofíticos. São Paulo: Departamento de Genética, Escola Superior de Agricultura "Luiz de Queiroz", 2002.

Arruda, E.; Melo-de-Pinna, G. F.; Alves, M. Anatomia dos órgãos vegetativos de Cactaceae da Caatinga pernambucana. Revista Brasileira de Botânica, v. 28, n. 3, p. 589-601, 2005. https://doi.org/10.1590/ S0100-84042005000300015

Ashraf, M.; Hasnain, S.; Berge, 0.; Mahmood, $\mathrm{T}$. Inoculating wheat seedlings with exopolysaccharide-producing bacteria restricts sodium uptake and stimulates plant 
growth under salt stress. Biology and Fertility of Soils, v. 40, no. 3, p. 57-162, 2005. https://doi.org/10.1007/s00374-0040766-y

Barreto, M. C. S.; Figueiredo, M. V. B.; Burity, H. A.; Silva, M. L. R. B.; Lima-Filho, J. L. Produção e comportamento reológico de biopolímeros produzidos por rizóbios e caracterização genética. Current Agricultural Science and Technology, v. 17, p. 221-227, 2011. https://doi.org/10.18539/ cast.v17i2.2052

Boari, C. A.; Alves, M. P.; Tebaldi, V. M. R.; Savian, T. V.; Piccoli, R. H. Biofilm formation by Aeromonas hydrophila and Staphylococcus aureus on stainless steel using milk and different conditions of cultivation. Ciência e Tecnologia de Alimentos, v. 29, no. 4, p. 886-895, 2009. https://doi.org/10.1590/ S0101-20612009000400029

Chang, W. S.; Van de Mrotel, M.; Nielsen, L.; Guzman, G. N.; Li, X.; Halverson, L. J. Alginate production by Pseudomonas putida creates a hydrated microenvironment and contributes to biofilm architecture and stress tolerance under water limiting conditions. Journal of Bacteriology, v. 189, p. 8290-8299, 2007. https://doi.org/10.1128/JB.00727-07

FAO - Food and Agriculture Organization of the United Nations. The state of the world's land and water resources for food and agriculture. Roma: FAO, 2011.

Guimarães, D. P.; Costa, F.; Rodrigues, M. J.; Maugeri, F. Optimization of dextran synthesis and acid hydrolis by surface response analysis. Brazilian Journal of Chemical Engineering, v. 16, no. 2, p. 129-139, 1999. https://doi.org/10.1590/S0104-66321999 000200004

Kavamura, V. N.; Santos, S. N.; Silva, J. L.; Parma, M. M.; Ávila, L. A.; Visconti, A.; Melo, I. S. Screening of Brazilian cacti rhizobacteria for plant growth promotion under drought. Microbiological Research, v. 168, no. 4, p. 183-191, 2013. https://doi.org/10.1016/ j.micres.2012.12.002
Montaldo, Y. C. Bioprospecção e isolamento de bactérias associadas à cana-de-açúcar (Saccharum officinarum L.) com características para a promoção de crescimento vegetal. Maceió: Universidade Federal de Alagoas, 2016. (Doctorate thesis).

Nocker, A.; Fernández, P. S.; Montijn, R.; Schuren, F. Effect of air drying on bacterial viability: A multiparameter viability assessment. Journal of Microbiological Methods, v. 90, no. 2, p. 86-95, 2012. https://doi.org/10.1016/j.mimet.2012.04.015

O’Toole, G. A.; Kolter, R. Initiation of biofilm formation in Pseudomonas fluorescens WCS365 proceeds via multiple, convergent signalling pathways: A genetic analysis. Molecular Microbiology, v. 28, no. 3, p. 449461, 1998. https://doi.org/10.1046/j.13652958.1998.00797.x

Paulo, E. M. Encapsulamento de Lactobacillus acidophilus por atomização em spray drying, utilizando exopolissacarídeos (EPS) produzidos por bactérias láticas. Feira de Santana: Universidade Estadual de Feira de Santana, 2010. (Doctoral thesis).

Pimentel, D.; Bberger, B.; Filiberto, D.; Newton, M.; Wolfe, B.; Karabinakis, E.; Clark, S.; Poon, E.; Abbett, E.; Nandagopal, S. Water resources: Agricultural and environmental issues. BioSciences, v. 54, p. 909-918, 2004. https://doi.org/10.1641/0006-3568(2004) 054[0909:WRAAEI]2.0.CO;2

Schiavão-Souza, T. D.; Yuhara, T. T.; CastroGómez, R. J. H.; Garcia, S. Production of exopolysaccharides by probiotic bacteria: Optimisation of the culture medium. Brazilian Journal of Food Technology, v. 10 , p. $27-34,2007$.

Silva, F. G.; Santos, I. B.; Sousa, A. J.; Farias, A. R. B.; Diniz, W. P. S.; Kuklinski-Sobral, J.; Freire, M. B. G. S. Bioprospecting and plant growth-promoting bacteria tolerant to salinity associated with Atriplex numularia L. in saline soils. African Journal of Microbiology Research, v. 10, p. 1203-1214, 2016. https://doi.org/10.5897/AJMR2016. 8202 
Silva, J. M.; Silva, R. V. C.; Oliveira, J. U. L.; Santos, T. M. C. Endophytic bacteria isolated from sugarcane: Water deficiency tolerance and biofilm production. Global Science and Technology, v. 11, no. 1, p. 1-8, 2018.

CC License information: This is an open-access article distributed under the terms of the Creative Commons Attribution License, which permits unrestricted use, distribution, and reproduction in any medium, provided the original work is properly cited. 